ial. The biggest drawing card when the new Museum opens on May 16 is expected to be one of these displays, that of the Whooping Cranes pictured in this article. Adding interest to this exhibit is the fact that the Saskatchewan Museum owns two of the ten Whooping Crane eggs known to be preserved in museums.

Other exhibits that have been collected by the Museum or donated to, it include items of interest to students of archeology, of paleontology, and of the history of the people of the recent past in the province, as well as many fascinating miscellaneous objects. The plant herbarium is being built up, stressing native flora. All these exhibits attracted an impressive total of over 30,000 visitors in 1954 .

A second aspect of the Museum's work is the field camp programme carried on in the summer. The excavations in search of fossils at Eastend in the Cypress Hills and in the Big Muddy area, and in search of artifacts at Mortlach and Gull Lake are good examples of this activity.

Finally, the Museum's programme is essentially an educational program. The fact that of all the Museum's visitors children respond most enthusiastically, in itself justifies the emphasis placed on education by Mr. Bard and his staff. But the education programme does not end with activities within the MIuseum building. It reaches beyond, through films like Pelicans of Last Mountain made available for public showings and through the miniature bird and animal displays circulated through Saskatchewan schools.

Mr. Bard feels that the most important contribution the new Museum can make will come through its greater facilities for extension of service to the public in a programme of conservation education. Although there is still much work to be done, and extra staff will be needed, the Museum is anxious to put this extended programme into effect as soon as possible. From the date of the official opening on May 16, the Museum will be open to the public during the following hours:

Monday through Friday (May to September) 10 a.m. to 5 p.m.; 7 p.m. to 9 p.m. Sat., Sun., and Holidays (May to September) 2 p.m. to 5 p.m.; 7 p.m. to 9 p.m.

\section{Watching Wild Life Through Glasses}

\author{
By David McDonald, Manor, Sask.
}

One of the most exciting forms of hunting which is growing in popularity and does not involve the use of a gun or a rod is watching wildlife, an all-year-round sport. This requires little equipment; attracts participants of all ages, and does not involve the molesting or destruction of the object sought.

In days gone by, before the existence of popular field-guides and binoculars, naturalists had to resort to "collecting" specimens in order to learn the identity or ascertain anything about the object that they had obśerved. Nowadays, however, armed with well illustrated field guides and high powered glasses he may study the wildlife in his own community and add to the growing fund of knowledge on their migrations, food, mating and other habits without having to resort to killing.

The popularity of this sport may be attributed simply to the fact that all forms of wild life are fascinating creatures, whose habits are lively and very interesting.

Here in Saskatchewan there is an ever growing body of these watchers. This can be seen by each new issue of The Blue Jay.

There are two very important things which we must do in order to be assured that the various forms of wild life will not be depleted. First, by protecting them as much as possible, not by ourselves alone but by: seeking the aid of our friends alone. Second, by seeing that they have adequate nesting and breeding grounds. We can help our wildlife to raise its young by not destroying prairie, forest or wooded areas. Too often we find that fire has destroyed many such large areas which would have served as an ideal shelter spot for our wild life during the summer and winter months.

As Saskatchewan is celebrating its Jubilee Year this summer, let us do our best to aid our wild life as much as possible. By doing. so, we will be repaid a good many times over, even if for no other reason than to be able to watch them through our glasses. 


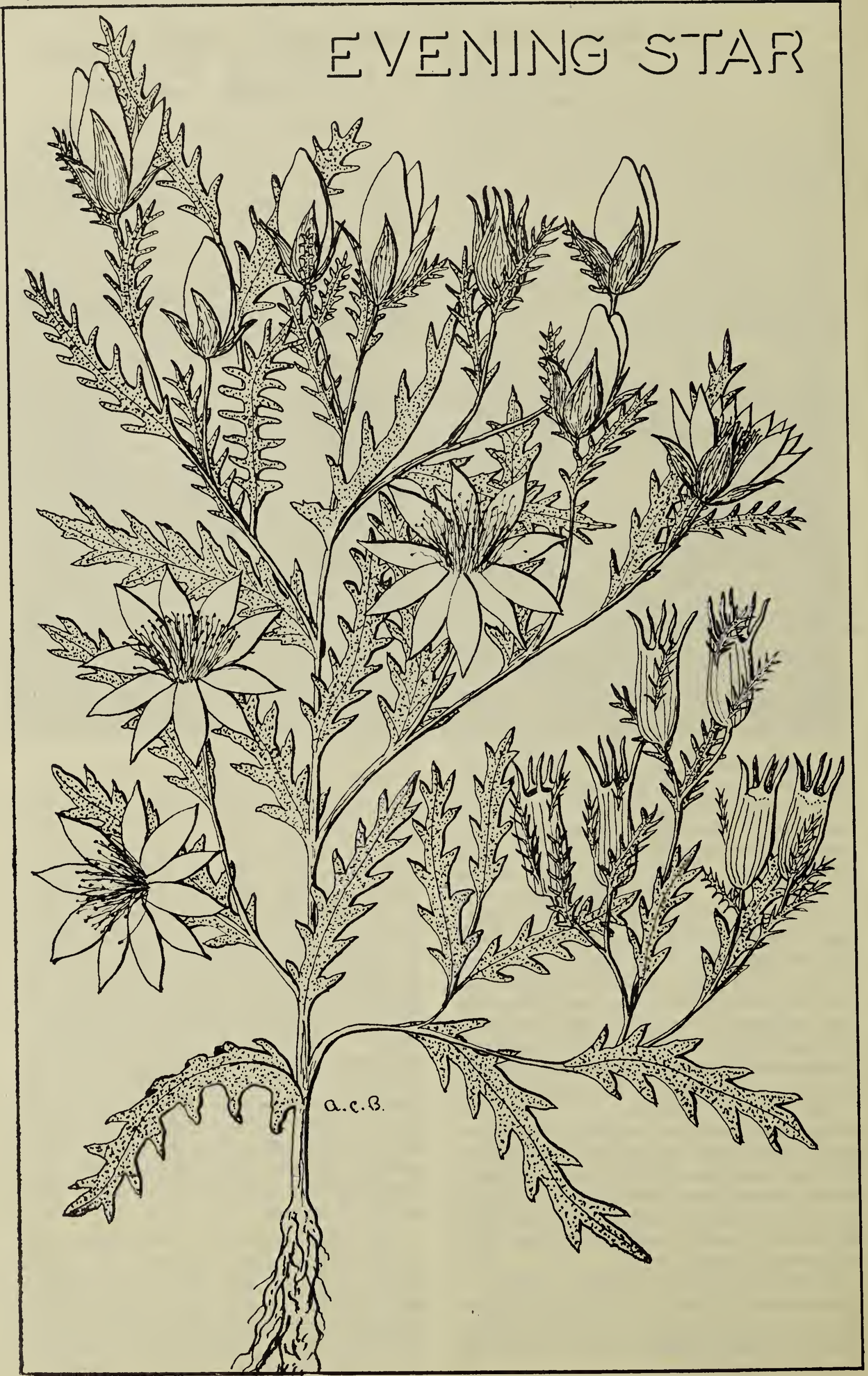

